\title{
IDP STABILIZATION ASSISTANCE: ROUTES TO OPTIMIZATION IN UKRAINE
}

\author{
Yuliia ZAVADOVSKA ${ }^{1}$ \\ Lviv National University of Veterinary Medicine and Biotechnology named after S.Z. Gzhytsky, Ukraine
}

\begin{abstract}
The purpose of the paper is to advise to optimization improvement pathways in IDP stabilization system in Ukraine that currently lacks real-time global-scale coordination, resulting in less efficient peaceful change. It is argued that with funding uncertainty, the system halts at middle level, aiming at sustainability. The article states that to improve, it needs to maintain high motivation and marketability of its professionals through skills and professional certification. Future grassroots projects should focus on mind changes. Methodology. A desk and in-depth study has been carried out of several national IDP stabilization programs dealing with the government that ensure infrastructural support to communities hosting IDPs. It has been studied how the programs "mindchange" their stakeholders (2014-2016 data) via regional NGOs and supports grassroots, using a real-time communication platform with features of cloud, internet banking, social network and dedicated server. Improving change generation tools, it leverages transformation with small, but not too small, resources to catalyze change. Results of the research showed that the bargain between external priorities and grassroots interests should favor program interest with "soft" projects, and listen to grassroots with "hard" projects. However, funding for non-state actors could have a 4-level structure, including: national projects for regional change strategies; regional NGO support funds; simple grassroots grants; and individual innovation prizes. Practical implications. Regional NGOs can improve beneficiary satisfaction and widen participation by supporting informal civic movements. For slowlyfunded programs, a pre-funding risk assessment report could be useful to assess change that is happening before the funding starts. Additionally, internships as a mind changing tool in IDP perception should focus on young professionals and high-ranked MPs, the latter to be engaged in group cooperation, aimed at professionalizing and strengthening their united voice to advance reforms in the region's governments, the $60+$ generation must give way to $50+$ reformers and build on $35+$ functional change-makers. Value/originality. The article concludes with the statement that we approach the need to establish an international coordination and control system, with IDPSA growing from an anti-poverty and democracy-building system - into the framework of support and stabilization the vital social functions in the regions of the world. While we agree that IDPSA in our region duplicates some functions of the state, therefore, it should be the state, supported by the global coordination system, which performs these functions directly - putting us closer to the developed economies and democracies of the world. According to the author, the structure of IDPSA might replace important sectorial functions in such states, building a humane world with common goals and aspirations of the higher values - where the combination of global security and humanism objectives and growth will be in harmony with the preservation of regional historical identity.
\end{abstract}

Key words: global coordination, internally displaced persons, support assistance, regional change strategies, grants programs.

JEL Classification: A13, J11, A23

\section{Introduction}

Over the previous 3 years the internally displaced persons stabilization assistance (IDPSA) system in Ukraine has successfully built a partially coordinated global organizational structure that effectively helped change the global balance of power, reform at self-governance levels and improve IDP living standards. However, the system lacks global focus and real-time coordination. Local partners and subcontractors became conservative, slow and not quite transparent. The consequence (Filyak, 1012) of these drawbacks is the low efficiency of real changes as well as distorted data on the assistance effect in target communities. Obviously, it's time to change - to improve

Corresponding author:

${ }^{1}$ Department of Economics of Enterprise, Innovation and Advisory Services in Agriculture, Lviv National University of Veterinary Medicine and Biotechnology named after S.Z. Gzhytsky. Email: zavadovska.j@gmail.com 
the system of IDPSA distribution, optimize financial flows, resolve the dynamics issue of the system and make it more flexible in interaction with grassroots organizations. Addressing these challenges, including the view of a government-integrated IDPSA global coordination mechanism, is the purpose of this essay.

\section{Basic organizational challenges of IDPSA system in Ukraine}

At the mid-level of IDPSA system in Ukraine, much organizational inertia has been accumulated so far, and the system itself tends to lose transparency. It looks like cells, once filled with workers and experts who now wish to keep their seats at all cost. Like an enterprise, once innovative and now with standardized products, with people who are now older and wishing a quiet retirement. Despite some rotation by age and expertize, the composition of the system at the level of IDPSA recipients has stabilized, and although it co-opts new individuals sometimes, this process is not as active as 3 years ago when organizational structures were actively formed and expanded. This huge mechanism in Ukraine is not receiving enough funding now and its expansion is not seen as viable - instead, optimization is brought to the front. But, once stabilized, its bureaucracy wants to continue its existence and carry out its meaningful social function - peacefully, without significant risks and overloads. This somewhat contrasts with the recent growth of tension in the world and questions as to implementation of the tasks in humanitarian international stability, which often rely on these organizations. Can it be that they do not want to perform their direct functions? The same can be said about the traditional, well-established national or regional NGOs - grantees or IDPSA subcontractors building bureaucracy, seeking stability. Therefore, conditions for professional development and improved loyalty should be created for the system's professionals, including those who are formally employed by national projects via local NGOs. On one hand, the professionals (citizens of the target countries) do not see prospects for future development, working from project to project, but on the other, they need certification and professional advancement - otherwise they realize that they remain uncompetitive in case of market exit.

\section{Integrating social movements in traditional NGOs}

Social movements, including those supporting IDPs, as opposed to formal NGOs are gaining popularity in Ukraine in the recent years. In particular, political mass actions are based on such movements and often funded by cash. Although the movements sometimes include unique personalities and seem to cost less, but they have a number of defects in their pure form, namely: irresponsibility, lack of grant professionalism, no chain of command, lack of prioritization and responsibility (e.g., neglecting the importance of transfer of experience), and no clear leadership. Therefore grants for regular activities framed in project performance matrices should be provided to the registered NGOs, which would then coordinate the activities of informal groups and social movements.

A solution exists, bringing together the human mass potential of social movement and the professional organizational and bureaucratic capacity of an NGO. Regional NGOs in this case should have «public», «youth» or «artistic» department or support an informal social movement, providing small grants in the form of cash prizes for its creativity and desire for social change. A formal NGO controls reporting schedule and quality of work of social movement on personal connections. It can lose funds, but not much. This "creative department" or partner movement will allow: 1) preparing future management and leadership from among the movement's youth and activists, 2) involving the masses of people in solving such local problems that really need wide public involvement, 3) a deeper and more accurate study of local beneficiary needs, resulting in recommending more contextually adapted solutions to the donor (improving bureaucratic, inflexible programs), 4) testing and implementing such social and cultural research projects that do not require traditional grant funding, but can be supported by crowd-funding or in-kind contributions of the implementing team. This last point is important in view of the relative cost efficiency of different types of social activities. There are some activities that are traditionally financed by donor, but can be implemented on a voluntary basis and by highly motivated people without project funds. At the same time, there are key activities relating to «basic support» in important public sectors, requiring control, consistency and bureaucracy, and accordingly, funds and organizational structure.

\section{Program instruments - prioritization versus localization}

The work in territorial development always contains a hidden conflict of interest. An IDPSA program declares its priorities, however, the local community insists on their own interests - often direct financial or infrastructural benefits, often neglecting social capital or education system improvements (Filyak, 2014). Hidden conflict of interest at grassroots level reduces program efficiency at the regional level.

If there are subcontractors between the donor and the grassroots level, they often adjust the harsh donor priorities to the local situation, softening requirements and interpreting them to bargain with the communities. On the other hand, sometimes the development program managed the career bureaucrats determines priorities too tightly and clearly. This approach can be understood on a national or regional level, because it contains a political component, or with soft (educational) projects, but at the community level, the program surely needs to be 
more flexible and context-adaptable, leaving the space for maneuver in the logical frameworks. It is necessary to carefully listen and hear the needs of local groups, avoid imposing the program views when the community really better knows what urgent issues they need to decide in order to move forward with achieving program priorities.

Projects for development of the region or the target country must be sufficiently flexible and adaptable as sometimes they will be funded 1-1,5 years after the submission of an application, and during that time the situation in the target country can change dramatically. For example, events in Ukraine 2013-2014 have restructured market for traditional NGO donor services and have «frozen» many projects, at the same time changing approaches to the programs that work with the government and youth and highlighted other priorities, primarily those associated with IDP support. In developing countries, events are often dynamic. Often, officials of development agencies located in conservative developed economies where no changes occur often do not realize how quickly the situation can change in developing countries. It is important that such change in the target countries is often led by young people living in the world of new views and rapidly changing technologies. These new trends and changes are often not completely understood by a generation of development program decision-makers.

For correlation of project documents, a mechanism of «risk report» could be established - to be developed by the authorized person of the future subcontractor 3-1 months before the acceptance of funding, containing a summary of ongoing change in the target country that might have affected the project document during the time when proposal was reviewed by the donor, and recommendations for amendments to the plan of activities and budget of the Project Document due to possible changes in the target country, that is already taking place. The authorized persons should have responsibility for the content of the recommendations and changes in such reports, as it might affect large budgets sometimes. The recipients of these reports in the donor office should be appointed from among the people who have ability to think flexibly in order to understand the novelty of change and dynamism inherent in young opinion leaders.

\section{Financial and institutional instruments: forms of subsidization at NGO / project level}

IDPSA in Ukraine is currently multi-vectored with different levels of funding. The frequently practiced delegation of grants programs to national and regional NGOs disperses finance and blurs the clarity of strategic plan - there are many different projects but an integrated impact-oriented strategy cannot be seen. IDPSA should directly implement the major projects focused on the impact in the region- through designated project offices instead of subcontracts to (inter)national NGOs. In addition, regional NGOs in target countries often lose the coordinating function for smaller NGOs and local action groups, in fact competing with them. At the micro-level, grant procedure for small NGOs and initiative groups is often overburdened by bureaucratic procedures, not fully transparent and difficult to report. This mechanism requires simplification in order to address real needs, highlight success stories and good ideas and models for further replication.

Therefore, funding mechanisms for non-state actors in the region can be structured as follows:

National level: targeted projects and programs in priority areas with its own national staff. The purpose is to reach strategic goals in transformation areas, impact on selfgovernance, advocate legislation improvement in favor of IDP support, and introduce a global IDPSA coordination mechanism integrated in the government. These projects are either widely distributed on a territory or focus in the central city, acting with the consent of the national government but without much interference.

Region level: large regional NGOs - as part of a global coordination mechanism, providing policy support "by sector" to self-governance. Basic support to smaller NGOs, those follow-up small grants at grassroots level. Stable support to social and health NGOs serving vulnerable groups.

Local level. Easy and transparent online mechanism of grants to local initiative groups incorporating IDPs to address their special needs as well as grants for starting new groups and «start-up ideas.» Easy in applying and reporting. Any initiative group can apply, cash transactions permitted. Reporting close to real time, budget operations can be tracked through an electronic system. Leaders of initiative groups are personally responsible for project.

\section{The lower margin of effective investment in change}

Donors in the region have been increasingly looking for clear linkage between the activities of an IDPSA program or a grantee - and the expected effect, and are willing to support only those activities, which act as a catalyst of change, with donor program budget as a kind of «lever» for initiation of such changes, and in fact using several times more of target country's resources to actually transform the situation. When the objective of the program is irreversible change in the region or locality, we should agree that it is necessary to finance the focal catalysts of such changes. Yet still, the funding agency should understand that there is a minimum limit of resources for investment in the territory, below which the "catalyzing of the change" will not occur and, consequently, local resources of the target territory will not be effectively involved in the donor's project to produce the replication and imitation effects and thus it will fail to get a much more significant support from local stakeholders. In other words, sometimes the donor does not want to «pour enough gasoline» in the fire of change, and it is not lighted or smoldering instead of igniting 
rapidly. Dollar prices in Ukraine increased so significantly over the past 15 years and up to the mid-2014 that small investments in change are obviously not enough. In comparison with early 2000s, consumer prices have grown by 2.5- 4 times in many countries in the region. Since the cost of living in Ukraine increased several times during the previous 15 years, and USD value to gold fell repeatedly, it is not possible in 2016 to expect sustainability plans, significant long-term effects and impact from a small grant project worth 2-5 thousand USD. Of course, there are exceptions, but generally small grants do not have a lasting impact. However, the application forms for some small grants programs often require to explain what his project will «impact» and which is the «long-term effect.» With the cost of one job creation in Ukraine of over 7000 USD (Pishchulina, 2009), it is difficult to speak of «effect» and «impact» from small NGO projects developing community infrastructure, or, even more so, when the project has a «soft» character (does not create physical infrastructure) and by its nature can not lead to any kind of significant «impact.» However, subcontractors of IDPSA agencies willingly request grantees to describe the «influence» and «effect» and sometimes even «sustainability after of the end of funding » - it seems they form their own progress reports based on these statements. However, in this case, at the highest IDPSA levels, a clearly exaggerated, distorted information is obtained, as small grantees (especially with «soft» grants) also distort their statements about the expected «impact» and «change», trying to get a grant. It seems senseless to require impact and change, and sustainable after-project funding models, from a small education or consulting project worth 3-5 thousands USD. Such funding for «soft» projects in Ukraine would be acceptable in form of a prize for an innovative idea, which can be replicated and used for a more ambitious development program in the region from which the idea came.

\section{Data and information technology: electronic grants support systems for IDPSA grassroots level}

To facilitate and simplify reporting, enabling project publicity in real time, quick support to beneficiaries and timely corrective action to achieve the desired strategic effects in the region, we suggest a software and consulting system. Organizationally, server software is hosted in

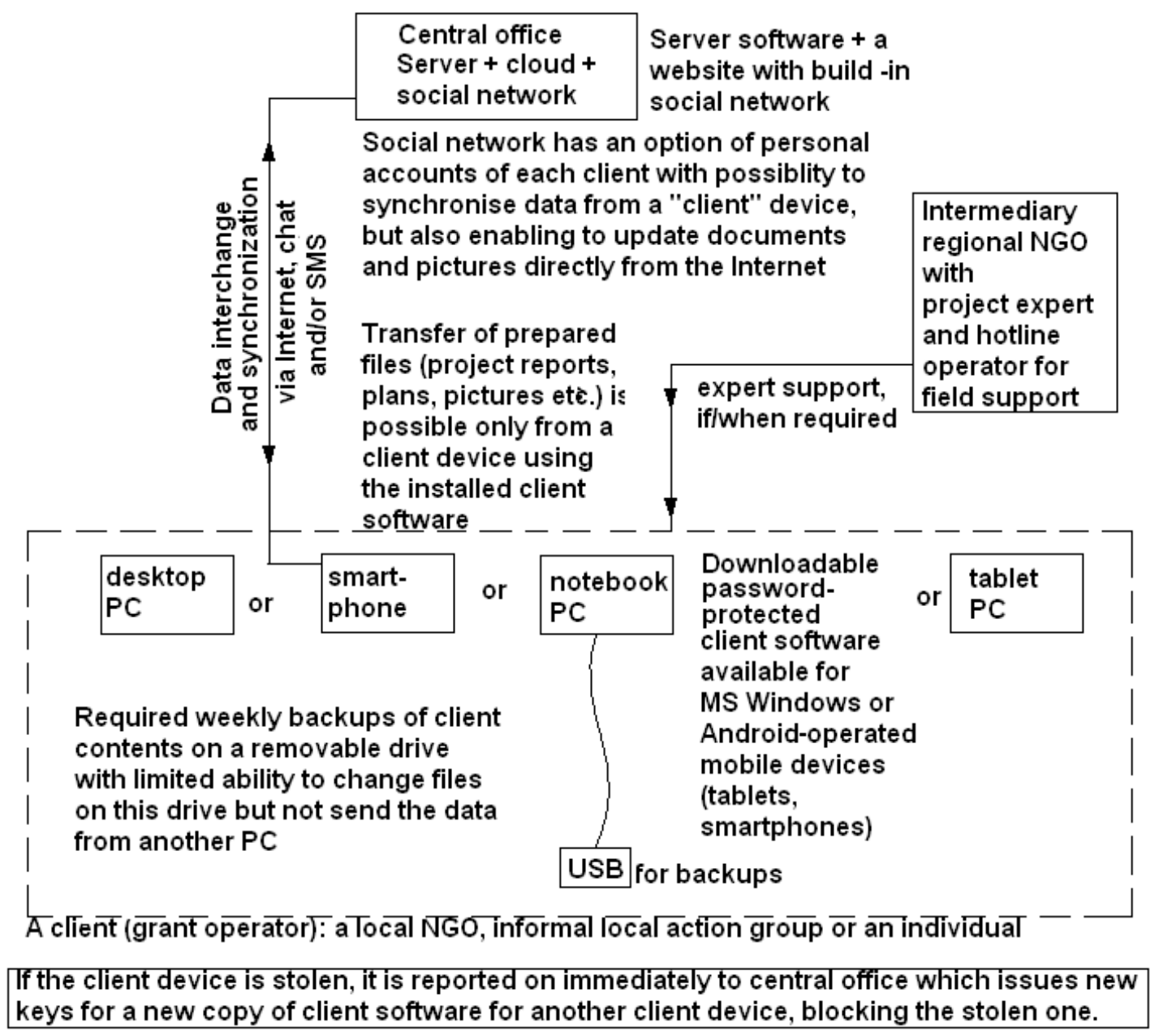

Fig. 1. Composition of electronic grants support system for IDPSA 
the donor office or a processing center, while the client software can be downloaded to the grantee's PC or mobile device and operated by an authorized person responsible for grant. This scheme also includes an organizational mediator - a regional NGO whose mission is to simplify and facilitate contact of grassroots grantees with the coordinating donor office. Such international system of electronic support might be logically structured as follows:

As you can see, the software can combine features of electronic banking payment systems, social networking, cloud technology and a call center. The system is designed for different conditions: when the quality of the grantees' Internet in good (constant connectivity with online web platform) or bad (preliminary preparation of documents on the «client» device and sending them afterwards, communication via SMS or a built-in chat to synchronize documents between the client device and its personal account on the web platform), and for different conditions of a grantee's available technical support (only 1 PC available, or a notebook, or tablet PC, or a telephone, or all these devices can be used). It allows using the existing platforms (organizationally - regional NGOs as support centers, offices of development programs, technically mobile operators' channels, existing software solutions in the field of cloud technologies, dedicated servers, social networks, and mobile banking) and is relatively inexpensive to organize. Instead, it will save time and will improve feedback of the grassroots grantees and even final beneficiaries with the donor agency - creating the ability to track changes and project activities in real time. In particular, the client software will have a button «complain to your donor». In this case, the information on the aims, objectives and expectations of the aid program is not lost for local/grassroots grantees and will not be falsely interpreted at the level of implementing partners or sub-contracting NGOs. This mechanism can provide a direct link between the very «top» decisionmaking level and the very «bottom» - for example, a small local NGO operating a micro-grant worth USD 1000 .

\section{Ukraine and IDPSA system: transforming youth attitudes}

Changing the minds and attitudes of the population through an IDPSA program can be seen as a key element of reform in Ukraine, as rather deep mental attitudes still remain in the population from the Soviet period. As part of such programs, foreign internships are practiced as a tool to share experiences and form new visions of opinion leaders and youth. The recent practice has shown that in this region, the internships are useful only for two categories of people - young future professionals and elected highranked public decision-making officials. Of course, there are others, including an academic scholarship system, but they are often not subject of IDPSA programs, and, as they do not involve actors of change, but rather focus on the development of science, we suggest assessing the efficiency of these 2 levels or types of internships within the IDPSA system.

The first level should be focused on future professionals (like chefs, technicians, veterinarians, waiters, and future professionals among IDPs - many of them young people, students) who obtain new experience and at the same time a motivation for higher living standards and civilizational development through participation in such events. Upon return, they would increase the cultural level of their region and the state, by adopting the best achievements of service, culture, business standards and technologies from abroad. These youth internships for independent specialists with an entrepreneurial mind stimulate the desire of a change for the better in Ukraine, with these people as advocates of change. Young beginners, independent narrow specialists, including entrepreneurs with commercial profile should be invited to such internships, because upon return, these people will have the right and jurisdiction to make their decisions and will have the possibility of change - at least in their own small business and in personal lives.

If the development program forms youth grassroots leaders inside the target countries, it should take care that in the long run, this leader remains motivated and with her/ his group, actually leading it. In addition, such programs could take care of proportional "dispersion" of leaders in social groups - to optimize control functions, rationalize competition and fill team management gaps.

\section{IDPSA and governance - transforming political minds}

Speaking of as a tool to improve governance, the second level should focus on high-ranked civil servants and elected representatives. In particular, Members of Parliaments of the rather centralized countries in Western NIS, who got an internship in other countries, are useful and highly experience and then link it to these new, efficient examples and models. Such internships are changing their minds towards the prospects of positive change in their country. After the trainings they have the technology for change and see how to improve the company, technology, economics; why it is done exactly this way and what other options are there. For greater efficiency and implementing the change in practice, such internships should link these "change technologies" to local level, in particular, compare sectorial policies and their legal regulation practices in the country hosting an internship and the country of origin. After seeing the positive difference abroad and understanding the legal way to have it at home, a parliamentarian can write a better bill enabling to develop a particular sector of the home economy, or improve social services, and change other national legislature. To sum up - such internship is useful for decision-makers to expand their horizons, gain technology and methods to resolve problems meeting social needs at home, through comparison and the 
following desire to bring the home country to the higher economic and socio-cultural standards. However, it doesn't pay off to show «a better life» to regional officials people without decision-making powers: they do not take strategic decisions and therefore cannot initiate change, especially in countries with centralized government. Selfgovernance (e.g., exchanges between city Mayors) is an exception though- with more decision-makers having influential voices and considering commercial use of the innovations they see.

We propose a model of effective internships with midlevel inclusion, where efficiency can be expected. This model suggests internships for the same organization but for hierarchically different levels of participants. The first internship is attended by official decision-making leaders, who will afterwards send their mid-level employees to second internship covering the same issues but focusing on implementation level. The change, resulting in internships, can occur if decision-makers (internship 1) see an institutional mechanism abroad allowing implementing changes, later giving clear guidance to subordinates (internship 2) to use this technology of change. In order to implement this, global IDPSA coordination mechanism should ensure monitoring of target reaching for change at the institutional level: through round table mechanisms to measure the real efficiency of civil servant internships and training, and through periodic discussions and consultations with former participants - now "changemakers". In addition, it is necessary to ensure that the key positions for change are occupied by competent "changemakers", able to implement a full cycle of innovation project development: starting from an idea and to the working product.

When using internships to achieve greater efficiency in the IDPSA global coordinating system, one should bring internship participants from Ukraine to the host country with the same level of centralization but a higher standard of living and societal development. Participants coming from a certain region need a new experience in a likely, but more developed, region in the host country. For greater efficiency, one should avoid culture shock of employees participating in training, creating a system of rapport instead, and strengthening contact points between the program and internship participants.

\section{References}

Filyak, M. «Managerial scratch notes» of Phase 1 Project. Gromadski Initsiatyvy. (13): 3-4.

Business planning in small cooperative entrepreneurship. Chasopys Publishing, 2013.

Filyak, M.S. Outcomes of Phase 2 micro projects' potential and sustainability analysis. Gromadski Initsiatyvy. (21): 8-16.

A National IDP Monitoring and Situation Analysis System (excerpts for Round 1). Gromadski Initsiatyvy (32): 2-10.

Pishchulina, O. New jobs in Ukraine: Results and Prospects. Department of Economics and Social Strategies. Retrieved from: http://old.niss.gov.ua/Monitor/october09/15.htm

\section{ЮлИя ЗАВАДОВСКАЯ}

\section{ПУТИ ОПТИМИЗАЦИИ РАБОТЫ СИСТЕМЫ СТАБИЛИЛИЗАЦИИ ВНУТРЕННЕ ПЕРЕМЕЩЁННЫХ ЛИЦ В УКРАИНЕ}

Аннотация. Целью работы является выработка рекомендаций по отношению оптимизации работы системы стабилизациивнутреннеперемещённыхлиц (ВПЛ) вУкраине, которой, помнениюавтора, нехватаетв реальном времени координации в глобальном масштабе, что приводит к снижению эффективности перемен в мирную сторону. Из-за неопределенности в финансировании система останавливается на среднем уровне, с целью обеспечения устойчивости. По мнению автора статьи, для улучшения в системе должны поддерживаться высокий уровень мотивации и самореализации её специалистов посредством улучшения их навыков и достижения профессиональной сертификации, а будущие низовые проекты должны быть направлены на изменение умов в сфере помощи ВПЛ. Методология. Было проведено кабинетное и фокус-групповое исследование ряда национальных программ по стабилизации ВПЛ, которые работают с правительством, таким образом обеспечивая инфраструктурную поддержку территориальным общинам, принимающим ВПЛ. Было изучено, как именно данные программы «изменяют восприятие» их выгодополучателей (данные 20142016 гг.) с помощью региональных НПО и поддерживают низовые группы, используя в режиме реального времени коммуникационные платформы с особенностями облака, интернет-банкинга, социальной сети и выделенного сервера. Улучшая инструменты генерации изменения, она использует преобразование ситуации с небольшими, но не слишком малыми, ресурсами для ускорения перемен к лучшему для ВПЛ. Результаты исследования показали, в целом, что сделка между внешними приоритетами и низовыми интересами должна способствовать програмному интересу в случае с «мягкими» проектами, а также слушать низовых партнёров с «жесткими» проектами. Финансирование негосударственных субъектов в сфере 
поддержки ВПЛ может иметь 3 уровневую структуру, в том числе: национальные проекты для стратегий региональных изменений; региональные фонды поддержки НПО; простые низовые гранты. Практическое значение. Региональные НПО могут повысить степень удовлетворенности получателей помощи и добиться расширенияучастия путем поддержки неформальных гражданских движений.Для медленно финансируемых программ, отчет об оценке риска перед предоставленим финансирования может быть полезным для оценки изменений, которые происходят ещё до начала финансирования. Вместе с тем, стажировки как инструмент изменения мировоззрения ВПЛ и функционеров системы их поддержки следует сфокусировать на молодых специалистах и высокопоставленных депутатах системы самоуправления. Данный инструмент должен быть направлен на профессионализацию и укрепление их единого голоса для продвижения секторных реформ в регионах и сообществах, и в этой сфере поколение $60+$ лет должно уступить дорогу реформаторам возраста $50+$ и опираться на функционеров возрастом $35+$ лет. Значение/оригинальность. Исследование завершается утверждением о том, что мы подходим кнеобходимости создания международной координации и управления системой, поскольку корни программ поддержки ВПЛ происходят из системы по борьбе с бедностью и из построения демократии - в рамках поддержки и стабилизации жизненно важных социальных функций в регионах мира. В то время как мы согласны с тем, что система поддержки ВПЛ в нашей стране дублирует некоторые функции государства, следовательно, она должна быть включена в государство, при поддержке глобальной системы координации, которая выполняет эти функции напрямую - и это приведёт нас ближе к развитым экономикам и демократиям мира. Структура системы поддержки ВПЛ может заменить все более важные функции, такие как построение гуманного мира в стране с общими целями и устремлениями высших ценностей - где сочетание глобальных целей, рост безопасности и гуманизм будут находиться в гармонии с сохранением региональной исторической идентичности. 